\title{
Overcoming the paradox of employers' views about older workers
}

\author{
Stephen Billett, Darryl Dymock, Greer Johnson (Griffith University, Australia) and Greg Martin
} (University of Technology, Sydney, Australia)

\begin{abstract}
In advanced and developing economies, ageing populations and low birth rates are emphasising the need for retaining and sustaining competent older workers. This paper examines policy and practice implications from the contradictory accounts directed towards those workers aged over 44 years whom are usually classified as “older workers”. It focuses on a key and paradoxical impediment in the retention of these workers in labour forces. That is, despite their increasing dependence on older workers, employers often position them as 'last resort' employees, hence inhibiting their access to employment, and the kinds of developmental opportunities and advancements afforded other categories of workers. Yet, in contrast, many older workers report being competent in their work; a view that is supported by other evidence. Using Australia as a case study, this paper argues that policies and practices to retain and sustain workers over 45 need to de-emphasise the term 'older workers' and re-consider how workplace environments and government policies, as well as practices by workers themselves, might pursue longer and more productive working lives for those aged over 45. It seeks to elaborate the paradox of the (under)valuing of older workers' contributions and provide direction for retaining and supporting the ongoing employability of these workers. It concludes by proposing that government, industry bodies and sector councils that seek to change employer attitudes will likely require a dual process comprising both engagement with older workers and a balanced appraisal of their worth. Alone, subsidies and/or mandation may well serve to entrench age bias without measures to redress that bias through a systematic appraisal of their current and potential contributions. In addition, to support this transformation of bias and sustain their employability, older workers will likely need to exercise greater agency in their work and learning.
\end{abstract}

\section{Retaining older workers and sustaining their workplace competence}

Countries with both advanced industrial and developing economies are facing significant public policy challenges arising from the changing demographics within their populations. In particular, the preponderance of older workers and relative shortage of new workforce entrants is skewing upwards the median age of national workforces. This situation has a series of implications for governments of these countries, including the difficulty of sustaining an adequate provision of welfare (e.g. health provisions and pensions), the capacity for aging workforces to produce goods and services that are competitive on the global market (i.e. exportable, but also import competitive), and having an adequately skilled workforce that can address changing social goals (e.g. provision of aged care). As a consequence, it is likely that many, if not all, countries with advanced industrial economies will need to retain the service of workers and sustain their employability beyond existing retirement ages. The focus on employability will include finding ways of maintaining these workers' workplace competence and deploying them more effectively across their working lives. Hence, identifying appropriate policies and practices to retain these workers and sustain their competence is becoming increasingly necessary to maintain these countries' social provisions and economic performance, including securing enterprise profitability and individual employability. Yet, redressing this issue is far from straightforward because it also requires confronting a paradox. That is, many of the employers and managers who are increasingly in need of their service, hold negative views about the work performance and adaptability of older employees, and will only employ and support their on-going development as a last resort. Yet, older workers consistently report themselves as anything other than last resort employees (Tikkanen et al 1997 and Dymock et al 2009). Rather, they often view themselves as being competent, able to lead productive working lives and demonstrate a capacity to adapt to new work requirements (Billett 2010); a view supported by other research, including that into older workers’ physical and cognitive capacities. 
This paper discusses this paradox, through a consideration of current attitudes, policies and strategies about employing and training older workers, largely from Australia, and how it might be redressed to accommodate and more fully utilise workers aged over 44 . It does this by reviewing some of the key issues influencing government policies and initiatives, and suggests the kinds of workplace practices that need to meet these workers' needs and workplace imperatives for sustain productive workers and for longer. It argues that policies and practices to promote the employability of older workers need to include dual processes that both engage employers with older workers, and also require an appraise their worth in terms of key employability capacities such as: i) being responsive to and adaptable with change, ii) to continue to develop further their capacities and iii) contribute to the development of other workers. These employability capacities are those identified in a recent study of employability and mature aged workers in Singapore (Billett 2010).

In doing this, first, the paper outlines the changing demographics occurring across many countries within both advanced and developing economies to indicate the extent and scope of this phenomenon, including issues of specific relevance to the Australian economy and workforce. The first section includes with a brief summary of the Australian policy context surrounding the employment, retention and training of older workers. The second section provides a summary of international accounts of employers' attitudes and practices towards older workers. In the third section, some of the more significant consequences of negative employer attitudes and practices are advanced before concluding with a proposal for establishing new attitudes, policies and strategies to assist older workers and their employers to engage in productive working relationships to sustain their employability in ways that redress the views offered in many current accounts.

\section{Changing demographics, labour market trends}

Like many other countries, over the next 40 years or so, Australia will have an increasing proportion of its population aged 65 or more, and at the same time a decreasing number of young people available as new entrants to the workforce (Australian Bureau of Statistics (ABS), 2008). Although not as 'at risk' as Japan, Korea and Singapore (see Table 1), anticipating sustained low fertility and increasing life expectancy, the ABS predicts that by 2050 some 26 per cent of the population will be in the upper age bracket, compared to 15 per cent aged 0 to 14 years. From these data, the median age of the Australian population (i.e. the age at which half the population is older and half is younger) is expected to increase from 38.2 years in 2010 to 45.2 years in 2050. By 2050, the median age of Australians will be equivalent to that defined as being 'older workers': 45 years and above. Australia is far from being an exception, however. Table 1 presents selected examples of increases in the median ages of populations from a mix of countries with advanced and developing economies.

Table 1: Projected median ages, selected countries, 2010 and 2050 (ABS, 2008, 3)

\begin{tabular}{lccc}
\hline Country & $\begin{array}{c}\text { Median age } \\
\mathbf{2 0 1 0}\end{array}$ & $\begin{array}{c}\text { Median age } \\
\mathbf{2 0 5 0}\end{array}$ & Difference \\
\hline Japan & 44.6 & 54.9 & +10.3 \\
South Korea & 38.0 & 54.9 & +16.9 \\
Singapore & 40.6 & 53.7 & +12.9 \\
Canada & 40.0 & 45.3 & +5.3 \\
Australia & 38.2 & 45.2 & +7.0 \\
China & 34.9 & 45.0 & +10.1 \\
New Zealand & 36.8 & 44.1 & +7.3 \\
UK & 40.0 & 43.4 & +3.4 \\
Vietnam & 26.9 & 41.6 & +14.7 \\
Indonesia & 28.2 & 41.1 & +12.9 \\
USA & 36.5 & 41.1 & +4.6 \\
India & 25.0 & 38.6 & +13.6 \\
PNG & 20.3 & 30.9 & +10.6 \\
\hline
\end{tabular}

A common trend in the data presented in Table 1 is the growing proportion of national populations whose median age will be classified at the age of being 'older workers'. Whereas in 2010, none of these countries has a workforce with a median age equivalent to the commonly 
accepted age for older workers (i.e. 45 years), by 2050 no less than six of those countries will have exceeded it. Yet, differences in demographics will likely play out across this range of countries in distinct ways. It is noteworthy that the rate of change in the median ages also differs, across these countries. From the ABS projections shown in Table 1, the median age of the Australian population in 2050 is expected to be about the same at that of Canada's, yet remain considerably below those of Japan, South Korea and Singapore respectively, but will be higher than those of the United Kingdom, and the United States. The selected developing countries, such as India and Vietnam, have high levels of projected increases, but from a relatively young population base in 2010. Then there are distinct differences, with for instance significant disparities between the educational levels of younger and older segments of the populations in some counties, for instance. But, commonly, the data in this table suggest that if the predicted trends eventuate, all these countries will continue to have a growing proportion of their populations who are in their fifth and sixth decades of their working lives, and whom governments and employers will be increasingly reliant upon to maintain levels of productivity and service and provisions of care.

Certainly, older workers are becoming increasingly prevalent, and wishing to participating more and for longer. In the twenty years from 1983 to 2003 the percentage of the Australian labour force aged 45-64 increased from 24\% to 32\% (ABS, 2004, 2). The ABS (2004, 2) noted that this increase was due not only to larger numbers of people entering the older age group, but also because of increased participation rates of older people in the labour force, particularly that by women. By June 2008, in a total labour force of just over 11 million, the percentage of workers aged 45-64 had increased to almost 35\%, with just over 2 per cent aged 65 or more (C. Kaida, DEEWR, personal communication, 30 June, 20008). In 2007, the average retirement age was 58.3 years for women and 61.5 years for men. An ABS survey taken that year, reports that 15 per cent of Australian workers aged 45 and more claim not to plan to retire, but will remain working until they die. Most claim an intention to reduce their level of work to become part-time workers. The survey suggests that less than 30 per cent of middle-aged and older Australians now intend to retire before they turn 65 (Colebatch, 2009). Significantly, these data were gathered in 2007 prior to the recent global economic downturn which, amongst other impacts, has seen Australian workers' superannuation (i.e. personal retirements funds) depleted by up to $40 \%$. Hence, a far higher percentage of Australian workers are now likely to postpone their retirement, than those who reported their intentions in 2007. Consequently, the retention levels beyond the existing retirement age are likely to increase in the foreseeable future. Moreover, in a move likely to be followed elsewhere, the Australian government is increasing the eligibility age for pension entitlements to 67 years.

Given these demographic trends successive Australian governments have become interested in how older workers can sustain their employability. Clearly, a major national concern is to avert labour shortages that would inhibit the provision of the goods and services required for maintaining and developing the level of the nation's social provisions and economic activities. The threat seems real. A recent Australian Government report (DEEWR, 2005) predicted that population aging will impact on all major industries and occupations, and across most Australian regions. Yet, policies and practices to bring about change may well have to occur at the particular sectoral level as the participation by older workers and their needs for employability is far from uniform across Australian industry sectors. Clearly, some occupations are more or less age tolerant: amenable to workers in their fifth or sixth decades. The most affected industry sectors are predicted to be agriculture, forestry and fishing; education; and health and community services, where almost half the workforce is already aged over 45 years (Neville, 2008). Retention of workers will become clear and urgent imperative and key policy goals for such industry sectors. Yet, as is proposed below, many, perhaps most, employers view older workers as being 'last resort' employees. Therefore, rather than wholeheartedly employing and advancing the interests of these workers the great risk is that they will engage with them partially and only reluctantly. One rather clear priority is to redress employer attitudes towards older workers. Yet, this needs to be undertaken in ways that seeks to change rather than entrench seemingly inappropriate attitudes about older workers. 


\section{Employer attitudes and practices towards older workers}

Quite consistently across international and national surveys, a pattern emerges of employers and managers holding older workers in low esteem that appear quite entrenched. Indeed, managers' assessments of older workers are consistently negative, seemingly irrespective of appraisals of their actual performance (Rosen \& Jerdee, 1988). The evidence from studies across Europe and North America commonly report that employers are far more likely to fund the training of the young and well-educated, rather than older workers (Brunello, 2001; Brunello \& Medio, 2001; Giraud, 2002). True, some northern European countries adopt more positive attitudes towards and claim a strong sense of obligation to older workers as exercised through a set of national policies and practices (Bishop, 1997; Smith \& Billett, 2003). Yet, it is noteworthy that elsewhere, the ways in which employers distribute and fund developmental opportunities for their employees, is resistant to legislated (Giraud, 2002) and mandated measures (Bishop, 1997). Instead, the privileging of youth (and perhaps never more so than when they become a scarce commodity within aging populations), is that which shapes employers' decision-making about the distribution of sponsored workplacebased opportunities for learning. This suggests that government intervention of pressing or subsidising employers to employ older workers will not be sufficient, unless the attitude of employers can in some way be transformed.

Australian studies of attitudes towards older workers report similar findings to those reported elsewhere. One study concluded that 'regardless of the perceived more positive qualities of older workers ..., employers appear to prefer to recruit employees in the younger age groups for most employee categories' with 'minimal interest in recruiting anyone over 45 years for any job ... and no preference for anyone 56 years or older' (Steinberg, Donald, Najman, Skerman, 1996, 157). Despite the increasing recognition of the looming labour shortage at that time and following it, such attitudes appear to have been slow to change. Yet, such attitudes are quite potent. Taylor and Walker $(1998,644)$ concluded that 'workplace perceptions about older workers (and different groups of older workers) may directly influence not only their prospects for gaining employment but also their prospects for development and advancement within an organisation'. A 2003 guide by the Business Council of Australia (BCA) identified numerous 'readily accepted negative stereotypes of mature-age workers', including their lacking motivation and enthusiasm, being closeminded, more susceptible to injury and illness, having out-dated skills, less capable, unwilling to take on new training or challenges, risk averse, and having less potential for development (p.12).

Yet, the issues raised by BCA (2003) and Jorgensen (2004) indicate difficulties in generalising about employer attitudes and practices. In a telephone survey of some 1000 enterprises in the business services sector, which included computer, legal, accounting and employment services, Bittman et al (2001) found no clear pattern of negative attitudes towards employing older workers. They claimed (p. vii) that 'despite [employers'] reputation for favouring younger, risktaking innovators, the study revealed a preference for a diverse workforce of intelligent, reliable, team workers with industry rather than computing experience'. However, Gringart, Helmes and Speelman (2005) claim the methodology used in that study did not allow respondents to systematically stereotype workers on the basis of age. Moreover, the business service sector may well be one of those better disposed to employing and supporting older workers than many others, as its work may be more age tolerant than others. Across a range of industries, a survey of 8000 Australian employers found the most proactive recruitment for mature age workers was in the finance sector ( $47 \%$ of firms), compared with only $32 \%$ in information technologies and $24 \%$ in telecommunications (Deare, 2006). This kind of difference indicates that employer attitudes are not uniform in their application or intensity, across industry sectors. For instance, in their 2001 study, Gringart and Helmes found that older female jobseekers were discriminated against more than males. Yet, four years later the same researchers, this time with Speelman (2005), found no significant gender difference. They concluded rather baldly that the sample of 128 'hiring decisionmakers' in businesses of up to 50 employees was generally unlikely to hire older workers. Either way, what these studies indicate is that employer attitude is central not only to whether older 
workers are employed or not and then retained, but also in advancing support for maintaining their employability through opportunities to develop further and apply more widely the knowledge they have learnt. Indeed, Howell, Buttigieg and Webber $(2006,6)$ concluded that senior managements' support for diversity and effective utilisation of older workers as part of the retail workforce resulted in age positive practices by those managers who supervise older workers. None the less, in its own way this kind of endorsement indicates, firstly, the importance of attitudes being premised on the basis of informed accounts of performance and not age bias, and , secondly, that these attitudes can change.

Such change in attitudes would need to be broadly applied across decision-making in businesses. For instance, the BCA (2003) claimed (p. 18) that voluntary retirement is often seen as a workforce management tool, but that such policies are often based on age alone, and that consideration is not given to the employees' skill and experience profiles. The depth and pervasiveness of the employer discrimination against older workers is illustrated further in the Business Council of Australia $(2003,11)$ findings that suggest recruitment agencies may actually practise 'ageism' when short-listing applicants for their clients', a claim quickly denied by the agencies (Hovenden, 2004). Certainly, some of these agencies promote mature age employment through their websites. One of them commissioned a report on the implications of the aging population in the Australian workforce that described ageism as 'a particularly insidious form of discrimination' (Jorgensen, 2004, 13). Recommending that employers needed to confront their own prejudices, Jorgensen also suggested (p. 13) that 'policy approaches that deal with ageism also need to be carefully framed so as not to stigmatise older workers, isolate younger workers or to impose obligations on older workers who simply do not have the health or desire to continue in full time or part time employment'.

It follows from here that in the current social and financial environments, specific and targeted policies and sustained initiatives are likely to be required to change attitudes about older workers' occupational capacities and employability across their working lives. However, these initiatives will need to overcome a range of societal and workplace barriers for the maximum retention of and full utilisation of these workers' capacities. Key barriers here include a societal preference of privileging youth over age across countries with advanced industrial economies. This preference manifests itself in workplace practices of not only favouring the employment of younger workers, but also directing far more resources towards their development than older workers, among other groups (Brunello 2001, Brunello and Medio 2001). These preferences seem powerful and enduring. Even evidence suggesting older workers are as capable as other workers and have the very attributes employers claim to value, seemingly fail to change views of those who employ and make decisions about workers' advancement and access to opportunities for development.

Some might argue that this preference will change as older workers become an increasingly common element of the workforce and a necessity for employers. Countering such a claim is the prospect that a scarcity of younger people may well lead to greater enterprise competition for and sponsorship of younger and well educated workers and more intense resourcing of these workers and away from older workers. Moreover, despite the growing presence of older workers in the Australian workforce over the last 20 years, little appears to have changed in terms of employer preference or workplace responses to their growing participation. Salient here is the comparison of older workers with women workers. Despite their increasing participation in the workforce, women workers across a range of national workforces have struggled to secure worthwhile work conditions, despite legislative arrangements associated with equal opportunity (Cavanagh 2008). Therefore, unless significant changes occur in both the attitudes towards and Australian employers' practices, older workers may well increasingly struggle to secure worthwhile work, and opportunities for the development and advancement required to retain them in socially and economically vital work and improve their effectiveness in that work. Indeed, there are potentially strong negative consequences here. 


\section{Consequences of negative employer attitudes and practices}

There are both personal and societal costs of employer attitudes and practices that discriminate unreasonably against older workers. These costs include the limits in range of employment options for these workers and difficulties becoming employed. Indeed, a consequence of policies designed to promote a deregulated and flexible labour market is the growing distinction between 'core sector jobs' ("good" jobs that require high skills, offer decent wages and provide benefits such as support for training and development) and 'peripheral sector jobs' (“dead end” jobs that require few skills, offer poor wages and few benefits, as well as little in the way of job security) (Kossen and Pedersen, 2008, p. 5). Given such a bifurcation, the great risk is that older workers will be seen as only being employable in the peripheral sectors. This may well be particularly true for the range of options that are available for many older workers. Challenging the notion of meritocracy in the labour market, Kossen and Pedersen cite research indicating that older workers who have been excluded from employment "experience far greater difficulty in rejoining the core workforce" (2008, p. 6). The point here is that older workers may have greater difficulty securing worthwhile work when they re-enter the workforce. Indeed, the negative attitudes older workers experience may well contribute to the widespread 'culture' of early retirement in Australia (Encel 2003) in which workforce participation by those over 55 is considerably lower than in many other OECD countries (ABS, 2007) as these workers fail to find meaningful employment, and withdraw from the labour market. A recruiting agency (Adage, nd, 1) concluded that mature age workers are more likely to 'experience the compounding effect of being out of the workforce resulting in being seen as less employable'. Another agency reported that nearly three-quarters of 2000 baby-boomers surveyed believed that it is nearly impossible to get a job after age 45 (Brinsden, 2007). The studies cited above, along with a range of other research findings (including those reviewed by Syed (2006) and Kossen and Pedersen (2008), and OECD (2006a \& b) confirm that age prejudice is alive and well in Australian workplaces, and likely plays out most heavily on those who are currently out of employment. Consequently, a priority for policy is to find ways of supporting unemployed older workers' re-employment, and in worthwhile work, and finding ways of praising their worth that can transform the attitudes of their employers.

Yet, others suggest that factors other than age alone play key roles in decision-making, particularly that such decisions are based on a business case, not on ageism. In an Equal Opportunity Commission seminar, Ranzijn $(2005,1)$ argued that 'in general, age discrimination is not a function of a negative attitude towards older workers, but based on an implicit cost/benefit analysis'. The OECD $(2006,10)$ also noted that a difficulty for employers with older workers is 'wages and non-wage labour costs that rise more steeply with age than productivity' and also that there are 'shorter expected pay-back periods on investments in the training of older workers as well as their lower average educational attainment'. Perhaps because of such imperatives, Encel (2003, 4) warned that age discrimination is 'commonly covert and evasive and easily masked'. Similarly, Bittman et al $(2001,46)$ reported to an Australian House of Representatives inquiry into older workers' unemployment that the latter were consistently advised they were 'over qualified for lower positions and under qualified for higher positions'. Whatever the reasons advanced by employers for not retaining or employing mature age workers, Ranzijn $(2005,8)$ pointed out that the changing demographics of the workforce will inevitably mean that employers will have to resort to older workers in order to maintain productivity, a point also made by the OECD in its 2006 report from a multi-nation survey.

However, such a pragmatic and expedient premise may not be the best one to proceed with. Despite becoming increasingly essential for the production of goods and services, older workers will continue to be seen as "last resort workers": at the bottom of employers' preferred kind of workers (Quintrell, 2000). Employees categorised in this way will often be a low priority for employer-sponsored development opportunities and support in the workplace (Billett \& Smith, 2003) of the kinds required to retain them and develop further their capacities. Hence, even if government support the re-employment of older workers it is likely that within the workplaces opportunities are still likely to be shaped by a cultural preference where youth is championed and 
privileged, and where age is seen as a natural decline (Giddens, 1997). Therefore, older workers cannot be confident of being afforded the kinds of employer support required to maintain their workplace competence and successfully negotiate work transitions. Moreover, given the privileging of youth, it is unlikely that older workers will make demands for employer funded training least they reinforce the sentiment of being a liability. Analogously, Church, (2004) refers to disabled workers who have particular needs for support, yet are strategic and cautious in their demands for workplace support including that from their co-workers, lest they be seen as liabilities in costconscious work environments.

Nevertheless, the widely held view among employers that older workers are less able and inflexible, and offer limited return on developmental opportunities is questioned by data arising from informants with direct experience of these workers. McIntosh (2001), for instance, notes that enterprises actually employing older workers value their contributions in quite distinct ways. Survey responses of nearly 400 American employers and human resource development managers characterised older workers as: a) being flexible and open to change, b) having up-to-date skills, c) interested in learning new tasks, and d) willing to take on challenging tasks. Furthermore, $68 \%$ of the respondents concluded that training older workers costs less or the same as training their younger counterparts; $57 \%$ reported that age does not affect the amount of time required to train an employee (14\% disagreed); and $49 \%$ believed that older workers grasp new concepts as well as younger workers (18\% disagreed). In all, this survey portrays older workers as ideal employees, which confounds the sentiment behind practices that distribute employer-funded support away from these workers. The exercise of this sentiment may also reflect the contradictory and confusing discourse that many older workers experience and try to understand in the workplace: they are essential to maintaining the production of goods and services, yet discriminated against in terms of the opportunities afforded them.

Despite the suggestion in the survey reported by McIntosh (2001), few studies effectively describe the reaction and role of older workers to the changing nature of work processes. Indeed, McNair, Flynn, Owen, Humphreys, and Woodfield (2004) claim their surveys indicate that most workers reported not being given assistance to negotiate new work roles and new work as their work life transforms. Hence, this reinforces not only the lack of support, but the need for and apparent success of these workers being able to independently develop their capacities. Consequently, policies and practices by government, industry bodies and industry sector interests may have to interweave both support for older workers re-employment or continuing employment, with processes that also attempts to transform the views and perspectives of employers. Yet, sitting in here also is the need to develop and support these workers' capacities to be agentic learners. Direct subsidies may well indeed reinforce the perspective that positions older workers as being deficient and worthy of societally incurred subsidies, and places employers as being only able to employ and promote the interests of these workers when such subsidies are available. It would seem then that policies and practices need to both engage employers with older workers and promote they are worth to his employers in a way which incrementally influences their decision-making. It is these kinds of engagement and developmental that will be required to both overcome and transform well entrenched preferences.

Therefore, all of the above points to the importance of identifying what has to be done to effectively retain and develop further older workers' employability. Added here is the prospect that the fewer available younger workers will be in high demand and, as such, are unlikely to select low status occupations such as aged care, as is already the case. Hence, and as noted, a key consideration for approaches to improving policy and practice for older workers is shifting employer attitudes towards a more positive accounting of the capabilities and potentialities of these workers. Policy reform is needed to respond to engage and inform to secure such a shift. Therefore, it is helpful to identify what has been done to bring about such changes, policy wise. 


\section{Australian policy initiatives}

Through a variety of policies and strategies, governments in Australia and elsewhere have been attempting to reverse trends towards early retirement and negative attitudes towards employing and advancing the interests of older workers. These initiatives are mainly based around restructured tax and superannuation arrangements, age discrimination legislation and regulations, and labour market strategies providing support to mature age job seekers (OECD, 2006). There is concern that the social inclusion policy platform for older Australians needs to be stronger (Naughton 2008). Certainly, there are efforts being enacted across states and territories. Although these efforts are not necessarily co-ordinated or supported by strong legislative foundation, hence they may be ineffective in transforming employers' views. For example, the Queensland Government (2008) developed a strategy around 'Experience pays' and assured employers that their 'most valuable asset in meeting the labour supply shortfall are experienced, mature-age workers'. Yet, despite this strategy, Price and Colley (2007) concluded, for instance, that although the Queensland Public Service (QPS) had policies in place to value and retain older workers, these exhortations did not seem to have translated into actions and outcomes. They also noted that the team-based working that was prevalent in the QPS and should have allowed older workers to help develop the skills of less experienced workers appeared to be practised in an ad hoc rather than systematic way.

Other Australian state governments have considered how to address the issues of an ageing workforce. For example, a review by the Victorian Government (2005) identified a number of characteristics of the age-related workforce, including that private sector enterprises are most likely to employ workers less than 20 years of age, and least likely to employ workers aged over 60 years, whereas government sector is most likely to employ older workers, and least likely to employ workers less than 20 years of age. Such practices may point to the need for "strategies to effect change in attitude and behaviour need to be customised to specific industry and workforce segments” (ANTA, 2004, 5). In early 2008, the New South Wales government released a report, Towards 2030: planning for our changing population, in which one of the strategic outcomes is 'A productive, skilled and adaptable workforce'. The report included the observation from a background paper prepared by Rolland (2007) that 'with a number of notable exceptions ... employers are failing to translate their understandings of the emerging labour market to tangible changes in strategic people practices' (p.30). All of this points to the entrenched preferences of Australian employers, and the importance of findings ways of transforming those preferences.

There is a growing sense of urgency about this transformation. At the national level, the current federal government has declared its commitment to increasing the proportion of working age people in the workforce, and mature age people are included in its 'Working age policy' (DEEWR, 2008, 129). The Federal Minister for Ageing in July 2008 expressed in-principle support for the Human Rights and Equal Opportunity Commission's community education campaign to combat discrimination against mature age workers (NSW Labor, 2008). In the 2010 Intergenerational Report (Treasury, 2010, xii), the Australian Government identified the ageing of the population as one of its key priority areas, noting the consequences for economic growth and the welfare budget, and proclaiming that 'it is critical that the Government continue to pursue productivity enhancing and nation building reforms through prudent investment in social and economic infrastructure, and policies to support skills and human capital development'. However, Weller (2007, 417 ) suggests that the 'human capital' discourses behind government employment policies 'rest on the assumption that older workers armed with motivation and vocational skills will be able to return to fulfilling work'. Rehearsing the points made earlier, she claims that policies to increase older workers' labour market participation 'will not succeed while persistent socially constructed age- and gender-typing shape labour demand'. That is, unless the decision-making and workplace practices change, human capital discourses are unlikely to succeed indeed. Through advancing such assumptions means placing a greater emphasis on changing societal and employer attitudes, not just through policies mandates, but also though targeted strategies to transform these biases. 
It follows, therefore, that there is a need to consider how societal attitudes about 'older' workers might be changed. There is a need to secure more positive attitudes, not the least because both the age prejudice and the business case approach appear to be at least partially premised on false assumptions. That is there is contrary evidence to whatever is informing the view of these workers as being last resort. Certainly, there seems to be a closer alignment between the views of older workers (Dymock et al 2009, Tikkanen 1999) and the literature that reports on the actual capacities of older workers, than what the literature reports about the views of managers and employers. However, it is important to coordinate and link up policies that comprise a social inclusion agenda "to ensure that they do not work against each other" (Wooden, Vanden Heuvel and Cully, 2001, 44-45). That is, policies and practice need to be aligned to both ensure the engagement of older workers and also attempt to transform societal attitudes through that engagement. Therefore, having considered the need for governmental and policy imperatives, the next section sets out the areas through which policy action may well be directed.

Consequently, it is necessary also to attempt to change employer attitudes through engaging with these workers. Yet, it is unlikely that the societal sentiment favouring younger workers will readily change, unless specific and targeted strategies are enacted.

\section{Towards new attitudes, policies and strategies}

The discussion above suggests that much still needs to be done to change employer attitude towards older workers. This change might best be realised through dual processes comprising engaging with and appraising these workers' worth. That is, through a process that supports both employment opportunities with enterprise-based accounting of the comparative worth of these workers. All of this takes time and requires considerable and sustained commitment from government, industry bodies and industry sector councils. In the meantime, but also to support and sustain the change in employer attitude, older workers or collectively may increasingly be required to rely more on their own agency in maintaining their workplace competence than younger workers. So, there is also the need to develop further these workers as agentic learners.

It seems that to bring about desired changes, the focus for policy and practice considerations needs to simultaneously engage employers of older workers and include a process whereby the contributions of these workers can be appraised and used to transform employers' perspectives. That will mean, change beyond the introduction of regulations or subsidies for the employment or re-employment of older workers. There also needs to be interlinked or entwined processes that press employers to reflect upon the contributions of these workers and thereby challenge their biases and prepared causes of action. Some associated initiatives might be to: i) de-emphasise the term 'older workers' to engage with a more helpful and positive titling of workers beyond 45 years of age, ii) a realignment of the existing classification of 'older workers' which more helpfully accommodate the scope of needs for workers who are aged anywhere between 45 and 70, and iii) consideration of how best workplace environments and government policies, as well as practices by workers themselves might be enacted to secure longer and more productive working lives for those aged over 45. In short, current deficit discourses used to describe workers aged over 44 need to be transformed through a process by which perceptions of and decision about older workers are more informed by evidence from practice. Additionally, the societal conditions and attitudes that are conducive for older workers to contribute productively in workplaces need to be drawing upon the evidence available and the views of these workers, rather than societal sentiments that are prejudiced and at odds with the available evidence. Instead, work environment and educational provisions need to be improved for workers to learn productively throughout their working lives, not just on commencement.

Perhaps the societal preference favouring youth may change more quickly than anticipated. However, if and where limited support for older workers is sustained, there will be the need for promoting further approaches to learning (i.e., personal epistemologies) that are agentic and include a critically reflective component in order to maintain sense of self and capacities to effectively negotiate work transitions. This kind of demand places much of the responsibility for skill 
development upon these workers, seemingly because of the attitudes and values of employers and managers. Older workers' agency might well impact beyond the need to take care of their own retraining. Expanding on the point made above that older workers' include a critically reflective view of themselves as older workers, is an opportunity for a shift in thinking about what it means to be an "older worker". The more familiar way has been to conceptualise older workers in terms of lifespan development and demise. This view has supported the current discourse of the binary opposition between older and young workers. Critical reflection that begins with a focus the evidenced capacities and potentials of older worker (Naegele and Walker, 2006) and leads to a reconstruction of age identities in society (Ainsworth, 2001). Although several government campaigns have sought to conduct such a reconstruction, especially in areas of marginalisation, greater agency is needed from those marginalised. It is suggested that workers aged 44 and over, officially classified as older workers need to talk back to a discourse that positions them as "last resort employees”. According to discourse theory (van Dijk,2008) changes to social action and how people are treated is replicated in how people are represented in spoken, written and visual texts.

\section{Changing perceptions about older workers}

In sum, utilising fully the capacities of workers aged over 44, developing their skills and providing rewarding working lives stands to be a growing concern for policy and practice in Australian workplaces and educational institutions, as it does in many other countries. Yet to achieve these goals requires more than efforts to support these workers' specific skill development. It also requires a change in societal views about the value of older workers, and that sentiment change needs to be particularly exercised in workplaces and by those who make decisions about employment, developmental opportunities and advancement. In sum, there needs to be a closer alignment between the ways in which competent older workers believe they are and the beliefs and practices of those that employ them, within a complex environment of public policy, societal sentiment, employer strategies and employee attitudes.

However, as has been proposed here the challenge to sustain older workers' competence cannot be addressed by further developing older workers' capacities alone. It also requires changing others' perceptions, especially those making decisions about the employment of and opportunities these workers. Yet, societal sentiments take time and effort to overcome, and are then not changed lightly. It therefore behoves older workers to take care of and for themselves, individually and collectively, and become agentic learners and workplace participants. In the foreseeable future, they will likely have to rely upon their own epistemological efforts to maintain their workplace competence. With these measures in place it is more likely that older workers will affirm their beliefs about being competent, up to the job, able to adapt and worthy of opportunities for development and advancement. Such affirmation, when coinciding with opportunities for employers to appraise the worth of these workers and challenge their own preferences may well lead to appropriate transformational change is that personal and societal levels.

\section{Acknowledgement}

The authors acknowledge the support provided by the Australian Research Council, through its International Linkage Social Science Collaboration program.

\section{References}

Ainsworth, S. (2001). The discursive construction of the older worker identity: A reflection on process and methods. Tamara: The Journal of Critical Postmodern Science, 1 (4, 29-46.

Adage, (n.d). Why Adage targets mature professionals, www.adage.com.au.

Ainsworth, S. \& Hardy, C. (2007), 'The construction of the older worker: privilege, paradox and policy', Discourse \& Communication, 1(3), 267-285.

Australian National Training Authority, (2004), Increasing the vocational education and training participation and achievement of older workers: ideas for action, Brisbane: ANTA.

Australian Bureau of Statistics. (2004), Paid work: mature age workers. Australian social trends series, catalogue no. 4102.0, 15 June, Canberra: ABS. 
Australian Bureau of Statistics. (2008), Population projections - a tool for examining population ageing. Australian social trends series, catalogue no. 4102.0, 15 June, Canberra: ABS.

Australian Bureau of Statistics. (2007), Skilling mature age Australians for work, Year Book Australia, catalogue no. 1301.0, 7 February, Canberra: ABS.

Australian Bureau of Statistics. (2004). Paid work: mature age workers. Australian social trends series, catalogue no. 4102.0, 15 June, Canberra: ABS.

Baltes, P. B., \& Staudinger, U. M. (1996), 'Interactive minds in a life-span perspective.' In P. B. Baltes \& U. M. Staudinger (Eds.), Interactive minds: Life-span perspectives on the social foundations of cognition (pp. 1-34), Cambridge: Cambridge University Press.

Billett, S. (2010). Promoting and supporting lifelong employability for Singapore's workers aged 45 and over. Singapore, Institute for Adult Learning

Billett, S. (2006), Work, change and workers. Springer: Dordrecht, The Netherlands.

Billett, S., \& Smith, A. (2003), 'Compliance, engagement and commitment: Increasing employer expenditure in training', Journal of Vocational Education and Training, 55(3), 251-269.

Bishop, J. H. (1997), 'What we know about employer provided training: A review of the literature', Research in Labour Economics, 16, 19-87

Bosman, E. A. (1993), 'Age-related differences in the motoric aspects of transcription typing skills', Psychology and Aging, 8(87), 87-102.

Brinsden, C. (2007), 'Mature-age workers pessimistic over future', The Australian, 9 July, online.

Brunello, G. (2001), 'On the complementarity between education and training in Europe': IZA discussion paper 309. (Forschungsinstituit zur Zukunft der Arbeit- IZA. (Institute for the Study of Labour).

Brunello, G., \& Medio, A. (2001), 'An explanation of international differences in education and workplace training', European Economic Review, 45(2), 307-322.

Business Council of Australia, (2003), Age can work: A business guide for supporting older workers, Melbourne: BCA.

Cavanagh, J. (2008), Women auxiliary workers' learning and discovering 'self' through work in Billett, S, Harties, C \& Eteläpelto, A (eds) Emerging perspectives of learning through work (pp. 67-82), Sense Publishing, BV, Rotterdam, The Netherlands.

Church, K. (2004), 'Dancing lessons: A choreography of disability in corporate culture.' Paper presented at the WALL Annual Meeting, Toronto.

Colebatch, T. (2009). 'Retirement by 70 a fading hope for many', The Age, 25 February, online.

Deare, S. (2006), 'IT and telecomms inactive on mature workers.' ZDNet Australia, www.zdnet.com.au/news/business/soa/IT-and-telecomms-inactive-on-matureworkers/0,139023166,139251015,00.htm.

Department of Education, Employment and Workplace Relations. (2008), 'Outcome 8: Workforce participation', DEEWR Budget Statements - Outcomes and Performance,

www.deewr.gov.au/deewr/Publications/Budget.

Department of Employment and Workplace Relations. (2005). Workforce tomorrow, DEWR, Canberra.

Dymock, D., Billett, S., Martin, G., \& Johnson, G. (2009, 24-26 June). Retaining and sustaining the competence of older workers: An Australian perspective Paper presented at the Lifelong learning revisited: What next? , Stirling University, Scotland

Encel, S. (2003), Age can work: the case for older Australians staying in the workforce. A report to the Australian Council of Trade Unions and the Business Council of Australia, Sydney.

Giddens, A. (1997), Sociology (3rd ed.), Cambridge: Polity Press.

Giraud, O. (2002), 'Firms' further training practices and social exclusion: Can industrial relations systems provide greater equality? Theoretical and empirical evidence from Germany and France.' In K. Schoman \& P. J. Connell (eds.), Education, training and employment dynamics: Transitional labour markets in the European Union, Cheltenham: Edward Elgar, pp. 300-303.

Gringart, E \& Helmes, E. (2001), 'Age discrimination in hiring practices against older adults in Western Australia: the case of accounting assistants', Australasian Journal on Ageing, vol 20, 23-28.

Gringart, E, Helmes, E, \& Speelman, C. (2005), 'Exploring attitudes toward older workers among Australian employers: an empirical study.' Journal of Aging and Social Policy, vol 17, 3, pp. 85-103.

Guest, R and Shacklock, K. (2005), 'The impending shift to an older mix of workers: Perspectives from the management and economic literatures', International Journal of Organisational Behaviour, Vol. 10, pp. 713-728.

Hovenden, D. (2004), 'Fishy memories on ageing workforce crisis,’ Human Resources Magazine. 
Howell, S., Buttigieg, D. and Webber, W. (2006), 'Management attitudes to older workers in the retail sector', Monash Business Review, Vol 2, 3, pp. 1-10.

Jorgensen, B. (2004), The ageing population: Implications for the Australian workforce. Sydney: Hudson Global Resources and Human Capital Solutions.

Kossen, C, and Pedersen, C. (2008), 'Older workers in Australia: The myths, the realities and the battle over workforce 'flexibility", Journal of management and organization, Vol 14, 1, pp. 73-84.

Naughtin, G. (2008). Social inclusion and older people. Brotherhood of St Laurence Social Inclusion Down Under Symposium Proceedings. Retrieved January 21, 2008, from http://www.bsl.org.au/pdfs/Naughtin_symposium_paper_26Jun08.pdf

McIntosh, B. (2001), An employer's guide to older workers: How to win them back and convince them to stay. www.doleta.gov/Seniors/other_docs/EmplGuide.pdf.

McNair, S., Flynn, M., Owen, L., Humphreys, C., \& Woodfield, S. (2004), Changing work in later life: A study of job transitions, University of Surrey, Centre for Research into the Older Workforce.

McNair, S, Maltby, T with Nettleship, S. (2007), Age, training and employment: a review of the literature.

Leicester: Centre for Research into the Older Workforce, NIACE.

Naegele, G and Walker, A (2006), A guide to good practice in age management, Dublin: European Foundation for the Improvement of Living and Working Conditions.

Neville, Ivan, (2008), 'The Australian Labour Market: Challenges and Responses', Seminar presentation, Canberra: Labour Supply and Skills Branch, Department of Education, Employment and Workplace Relations, www.gemspl.com.au/bipartite2008/Proceedings/Ivan\%20Neville\%20Presp.pdf

NSW Government. (2008), Towards 2030: Planning for our changing population, Sydney: NSW Department of Premier and Cabinet.

NSW Labor. (2008). Supporting older workers, 9 July, NSW Labor, www.nswalp.com/blog/358/supportingolder-workers.

Organisation for Economic Co-operation and Development. (2006a), Live longer, work longer: A synthesis report, Summary, www.oecd.org/els/employment/olderworkers, Paris: OECD.

Organisation for Economic Co-operation and Development, (2006b), Live longer, work longer: A synthesis report, Paris: OECD.

Price, R. and Colley, L. (2007), ‘Assessing HR strategies for retaining an aging workforce’, In: 15th International Employment Relations Association Conference: Working Lives, Working Choices, 913 July, Canterbury, England.

Queensland Government. (2008), Experience pays pack, Brisbane: Department of Employment and Industrial Relations.

Quintrell, M. (2000), Older and wiser; or just at the end of the line? Westminster Studies in Education, 23, pp. 19-31.

Ranzijn, R. (2005), 'Discrimination against the older worker: psychology and economics', Seminar paper, 'Of working age', May, Human Rights and Equal Opportunity Commission, Sydney.

Reserve Bank of Australia. (2007), Trends in employment and labour supply, September, Reserve Bank Bulletin.

Rolland, L., (2007), ‘Ageing and Work in 2030: In or out of our hands?’ Paper prepared for forum, ‘Ageing 2030 - Creating the future', Sydney: NSW Government.

Rosen, B., \& Jerdee (1988),, T. H. Managing older workers' careers . Research in Personnel and Human Resources Management, vol. 6, pp. 37-74.

Rupp, D. E., Vodanovich, S. J., \& Crede, M. (2006), 'Age bias in the workplace: The impact of ageism and causal attributions', Journal of Applied Social Psychology, 36, pp. 1337-1364.

Shacklock, K., Fulop, L. and Hort, L., 2007,Managing older worker exit and re-entry practices - a "revolving door"?, Asia Pacific Journal on Human Resources, 45(2), 151-167.

Sigelman, C. K. (1999), Life-span human development (Vol. 3), Pacific Grove: Brooks/Cole Publishing Company.

Smith, A., \& Billett, S. (2003), Enhancing employers' expenditure on training. Adelaide: National Centre for Vocational Education Research.

Steinberg, M, Donald, K, Najman, J, Skerman, H. (1996), Attitudes of employees and employers towards older workers in a climate of anti-discrimination, Australian Journal on Ageing, vol 15, 4, pp. 154158.

Syed, Jawad (2006), Older workers in Australia: A policy perspective. Journal of Economic and Social Policy,Vol. 1, 11, pp. 21-43. 
Taylor, P and Walker, A. (1998), Employers and older workers: Attitudes and employment practices. Ageing and society, 18, pp. 641-658.

The Treasury. (2010), Australia to 2050: future challenges (Intergenerational Report), Canberra: Australian Government.

The Treasury. (2004), Australia's demographic challenges, Treasury-Social policy division, Canberra.

Tikkanen, T. (1997, May). Consequences of unemployment on professional competency. Paper presented at the Nordic Conference on Adult Education, Trondheim, Norway.

Tikkanen, T., L. Lahn, Ward, P \& Lyng, K. (2002). Working life changes and training of older workers. Trondheim, Vox.

van Dijk, T.A. (2008). Discourse and Power. New York: Palgrave Macmillan

Victorian Government. (2005), The ageing workforce, The State of Working Victoria Project, Information Paper No. 4, Melbourne.

Weller, S. (2007), Discrimination, labour markets and the labour market prospects of older workers: what can a legal case teach us? Work, employment and society, 21, 417-437.

Wooden, M., VandenHeuvel, A. \& Cully, M. (2001) /Barriers to Training for Older Workers and Possible Policy Solutions, Adelaide: DETYA/NILS, Flinders University. 